\title{
溝付管を利用した振動流による熱輸送向上の研究*
}

$\begin{array}{llllll}\text { 本 } & \text { 達 } & \text { 也*1, } & \text { 大 } & \text { 野 雄 } & \text { - } 22 \\ \text { 菱 } & \text { 田 } & \text { 誠*3, }, \text { 田 } & \text { 中 } & \text { 学*3 }\end{array}$

\section{Augmentation of Thermal Energy Transportation by an Oscillatory Flow in Grooved Ducts}

\author{
Tatsuya MOTOKI, Yuuichi OHNO, \\ Makoto HISHIDA*4 and Gaku TANAKA \\ ${ }^{*}$ Department of Electronics and Mechanical Engineering, Chiba University, \\ 1-33 Yaoi-cho, Inage-ku, Chiba-shi, Chiba, 263-8522 Japan
}

\begin{abstract}
This paper deals with heat transportation by oscillatory flow in grooved ducts. The heat transportation rate, work rate, heat transportation efficiency and variances of fluid particles and heat were analyzed with the computer code FLUENT. The frequency and amplitude of the oscillatory flow was $0.05 \mathrm{~Hz}$ and $45 \mathrm{~mm}$. The internal diameters of the contraction section and the expansion section were 6 and $12 \mathrm{~mm}$ respectively and the length of the contraction section was fixed to be $10 \mathrm{~mm}$ with the length of groove varying from 0 to $40 \mathrm{~mm}$. We found: (1) Heat transportation rate reached about 4.5 times as large as that of smooth round pipe at the groove length of around $10-15 \mathrm{~mm}$. (2) Heat transportation efficiency increased to about 6.4 times that of smooth pipe at the groove length of $20 \mathrm{~mm}$. (3) The dispersion of fluid particles caused the augmentation of the heat transportation of grooved ducts with $40 \mathrm{~mm} \geqq$ groove length $\geqq 5 \mathrm{~mm}$. (4) The grooved ducts with the groove length of $10-15 \mathrm{~mm}$ had the maximum value of the variance of fluid particles which accounted for their high heat transportation rates.
\end{abstract}

Key Words: Heat Transfer, Heat Transfer Enhancement, Heat Pipe, Heat Transportation, Oscillatory Flow, Grooved Duct, Numerical Analysis

\section{1. 緒 諭}

電子機器や電子デバイスの小型・高性能化等に伴い 小型で熱輸送密度の高い熱輸送デバイスの開発が期待 されている. その中で，振動流を利用した熱輸送管も 有望な候補の一つとみなされている.

振動流を利用した熱輸送管が Kurzweg(1)により考案 されて以来, 多くの研究者によって性能の改善が試み られてきた. Kaviany(2)は管壁と振動流との間の非定 常熱伝達を利用することにより熱輸送性能が向上する と報告している，西尾ら(3,4)は振動流を熱輸送に利用 する場合の最適条件について検討を行っている.すな わち, 液体の物性, 管径, 振動条件, 流れの状態 (層 流・乱流）と振動流の熱輸送特性との関係を詳細に検 討している. 更に, 西尾らは従来の振動流熱輸送管 より高い熱輸送效率を有する逆位相振動制御形熱輸送 管を提案している. 大野ら向は高周波領域におりる熱 輸送効率の低下を改善する一つの方法として二重管の 利用を提案している. 犬飼ら(は振動流成分に定常流

\footnotetext{
* 原稿受付 2006 年 2 月 20 日.

*1 千葉大学自然科学研究科(昰2 263-8522 千葉市稲毛区弥生町 1-33).

*2 (株) デンソー( $\overline{\mathbf{w}}$ 448-8661 刈谷市昭和町 1-1).

$* 3$ 正員, 千葉大学工学部.

E-mail : hishida@ faculty.chiba-u.ac.jp
}

成分を重畳させた脈動流を利用することにより熱輸送 性能が改善できることを数值解析によって調べている.

一方，Ye と清水(8) は溝付管に振動流を与えた場合 の物質輸送の研究を行っている. 溝付管に与える振動 流の周波数，振幅及ひ溝付管の溝幅を変えて物質輸送 量を調べ，実効物質拡散係数が直円管に比べて最大で 100 倍程度向上する場合もあると報告している．彼ら は，溝付管に振動流を与えた場合に高い実効物質拡散 係数が得られるのは，渦の生成と放出に伴い，溝内の 流体と直管部の流体との混合が促進されるためである と報告している．また，Sobey(9) は波状流路に振動流 を与えた場合の流れ場の解析と流体粒子の分散運動の 解析を行っている. Sobey は，波状流路に振動流を与 えると，窪み内に非定常渦が形成され，この非定常渦 の形成と放出によって流体粒子が半径方向と軸方向に 分散し，その結果流体の混合が促進されると同時に軸 方向の拡散も促進されると報告している。

本研究の目的は，(1) 溝付管に振動流を与えた場合 の熱輸送量や熱輸送効率等が溝幅によってどのように 変化するかを調べること，及び，(2) 振動流によって 溝付管内に生じる流体粒子の分散運動が，熱輸送量に どの程度寄与しているかを検討すること，である。 


\section{2. おもな記号}

\begin{tabular}{|c|c|c|}
\hline$D_{\text {eff }}$ & ： 実効熱拡散係数 & $\mathrm{m}^{2} / \mathrm{s}$ \\
\hline$d$ & ：＼cjkstart縮小部の内径 & $\mathrm{m}$ \\
\hline de & ： 溝付管の等価直径 & $\mathrm{m}$ \\
\hline$L$ & ： 溝付管の長さ & m \\
\hline$P$ & ：圧力 & $\mathrm{Pa}$ \\
\hline$Q$ & ： 時間平均熱輸送量 & W \\
\hline$S$ & ： 溝の長さ, & m \\
\hline$T$ & ： 1 周期の時間, & s \\
\hline$u$ & ： $\mathrm{x}$ 方向の速度, & $\mathrm{m} / \mathrm{s}$ \\
\hline $\boldsymbol{v}$ & ： r方向の速度, & $\mathrm{m} / \mathrm{s}$ \\
\hline$V$ & ： 溝付管の容積 & $\mathrm{m}^{3}$ \\
\hline$W$ & ： 仕事率 & W \\
\hline$\theta$ & ： 温度, & $\mathrm{K}$ \\
\hline$\sigma^{2} f$ & ：流体粒子の分散, & $\mathrm{m}^{2}$ \\
\hline$\sigma^{2} t$ & ： 熱の分散, & $\mathrm{m}^{2}$ \\
\hline$\eta$ & ： 熱輸送効率 $(=\mathrm{Q} / \mathrm{W})$ & - \\
\hline
\end{tabular}

\section{3. 数 值 計 算}

図 1 に解析モデルを示す. 溝の無い部分の縮小部 の内径は $6 \mathrm{~mm}$, 溝部の内径は $12 \mathrm{~mm}$ (溝梁さ $3 \mathrm{~mm}$ )で ある. 溝幅 $S$ は $0 \mathrm{~mm}$ から $40 \mathrm{~mm}$ まで図 1 に示すよ

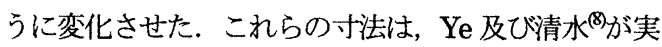
験で用いた溝付管の寸法とほぼ同じである. 管長 $L$ は約 $500 \mathrm{~mm}$ とした。管の端部の影響が及ぶ範囲は最 大でも管の両端部から $150 \mathrm{~mm}$ 程度であり，管路中央 部の速度分布や温度分布は無限長の溝付管内の速度分 布や温度分布と同じであると考えられる. 作動流体は, 水 (プラントル数 $=4.7$, 熱拡散係数 $\alpha=0.15 \times 10^{-7} \mathrm{~m}^{2} / \mathrm{s}$, 動粘度 $\nu=0.7 \times 10^{-6} \mathrm{~m}^{2} / \mathrm{s}$, 密度 $\rho=1000 \mathrm{~kg} / \mathrm{m}^{3}$ )である. 流れは 2 次元軸対称流であると仮定した。基礎式は 以下のとおりである.

$\frac{\partial u}{\partial x}+\frac{\partial v}{\partial r}+\frac{v}{r}=0$

$\frac{\partial u}{\partial t}+u \frac{\partial u}{\partial x}+v \frac{\partial u}{\partial r}=-\frac{1}{\rho} \frac{\partial p}{\partial x}+v\left[\frac{\partial^{2} u}{\partial x^{2}}+\frac{1}{r} \frac{\partial}{\partial r}\left(r \frac{\partial u}{\partial r}\right)\right]$

$\left.\frac{\partial v}{\partial t}+u \frac{\partial v}{\partial x}+v \frac{\partial v}{\partial r}=-\frac{1}{\rho} \frac{\partial p}{\partial r}+v \frac{\partial^{2} u}{\partial x^{2}}+\frac{\partial}{\partial r}\left(\frac{1}{r} \frac{\partial(r v)}{\partial r}\right)\right]$

$\frac{\partial \theta}{\partial t}+u \frac{\partial \theta}{\partial r}+w \frac{\partial \theta}{\partial x}=\alpha\left[\frac{\partial^{2} \theta}{\partial x^{2}}+\frac{1}{r} \frac{\partial}{\partial r}\left(r \frac{\partial \theta}{\partial r}\right)\right]$

上式を以下の境界条件の下で解いた。 $x=0$ (左端)で $u=0.0045 \pi \cdot \sin \left(\frac{\pi}{10} \cdot t\right), v=0$,

$\theta=323($ for $u \geq 0), \quad \frac{\partial \theta}{\partial x}=0($ for $u \leq 0)$

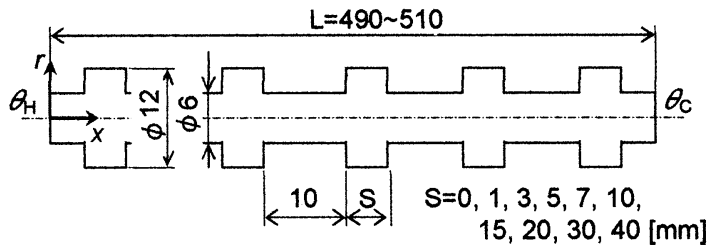

Fig.1 Analytical model of grooved duct

すなわち, 溝付管の左端に，周波数が $f=0.05 \mathrm{~Hz}$ で, 振幅が $A m=0.045 \mathrm{~m}$ の正弦関数状の振動流を与えた. また, 流速が正の場合には, $\theta=323 \mathrm{~K}$ の高温流体が 流入し, 流速が負の場合には, 軸方向の温度勾配がゼ ロとなる状態で流体が流出するとした.

$x=$ 約 0.5 (右端)で, $\frac{\partial u}{\partial x}=0, v=0, p=1.01 \times 10^{5}$,

$\frac{\partial \theta}{\partial x}=0($ for $u \geq 0), \quad \theta=293($ for $u<0)$

すなわち, 右端では, 圧力が一定で $\boldsymbol{u}$ の軸方向勾配 をぜロとした，また，左端と同様な温度条件を与えた， $r=0$ (中心軸上) で, $\frac{\partial u}{\partial r}=0, v=0, \frac{\partial p}{\partial r}=0, \frac{\partial \theta}{\partial r}=0$ (7) 壁面上で, $u=v=0, \partial \theta / \partial x=0, \partial \theta / \partial r=0$

本解析では, 振幅が $A m=0.045 \mathrm{~m}$, 周波数が $f=$ $0.05 \mathrm{~Hz}$ の振動流を溝付管の左端に与えたが, この条 件は樎小部の内径 $d$ を代表長さとするレイノルズ数 $\operatorname{Re}$ の最大值が 121 , 縮小部におけるストークス層厚 さを代表值径とするレイノルズ数 $\mathrm{Re}_{\delta}$ が 43 に相当す る. また, ウォマスリィ数 $\mathrm{Wo}=(d 2)\left(2 \pi f f_{N}\right)^{12}$ は 2.0 で ある.これらの值を Ye及び清水 ${ }^{(8)}$ 実験条件 $(\mathrm{Am}=$ $0.014 \sim 0.043 \mathrm{~m}, f=0.25 \sim 2.0 \mathrm{~Hz}, \mathrm{Re}=210 \sim 13,000$, $\operatorname{Re}_{\delta}=40 \sim 1000, \mathrm{Wo}=3.76 \sim 10.64$ ） と比較して分かる ように，本解析では $\boldsymbol{t}$ とReの值を彼らの值より小さ く設定した.これは，以下に理由による.

日野ら (10) は, 直円管内における振動流はストーク ス層厚さを代表直径とするレイノルズ数 $\operatorname{Re}_{\delta}$ が 550 以下の場合に層流であると報告している. しかしな がら，溝付管内の振動流においては， $\mathrm{Re}_{\delta}$ の他に管径 を代表直径とする Re の値によっても流れの区分は異 なると考えられる. 本解析では, 流れが層流となるよ う, Re の最大值を $121, \mathrm{Re}_{\delta}$ を 43 と小さい值に設定 した. そのため, $f$ を $0.05 \mathrm{~Hz}$ とした. また，予備実 験によって溝幅が $10 \mathrm{~mm}$ の場合の溝中央部における 流速分布を PTV 法により測定し, 解析結果と比較を 行い，両者の一致が良好であることを確認している.

計算格子は軸方向, 半径方向ともに等間隔に $1 \mathrm{~mm}$ あたり 10 分割とした．溝付管全体の計算格子数は 150,000 から 273,000 である. 計算格子の妥当性を検 
討するため, $S=3 \mathrm{~mm}$ の場合について $1 \mathrm{~mm}$ あたり 10 分割 $(185,400$ メッシュ) と 16 分割 $(474,624$ メッシ 工）の格子, $S=40 \mathrm{~mm}$ の場合について 10 分割 $(273,000$ メッシュ) と 20 分割 $(1,092,000$ メッシ ユ）の格子を用いた計算結果を比較したところ, 熱輸 送量の相違は最大で $1 \%$ 程度, 仕事量の相違は $0.3 \%$ 程 度であった．また，直管（ $S=0 \mathrm{~mm} ）$ の場合の熱輸送 量, 実効熱拡散係数, 仕事率及び熱輸送効率を Kaviany(2) による理論解と比較したところ，それぞれ 誤差 $0.29 \%, 0.24 \% ， 0.68 \%$ 及び $0.43 \%$ 以内で一致し た.これらの結果から， $1 \mathrm{~mm}$ あたり 10 分割したモ デルによる解析結果は妥当であると思われる.

数值解析には沉用流体解析ソフト FLUENT (11) を用 いた. 離散化には有限差分法を用い, 対流項は 2 次 精度風上差分法, 圧力補正は 2 次精度スキーム, 速 度と圧力のカップリングには SIMPLE 法を用いた. 時間の離散化には 1 次精度の陰解法を用いた。

\section{4. 解析結果及び考察 \\ 4.1 熱翰送量，仕事率、熱翰送効率}

解析によって求めた速度場と温度場から次式によ つて熱輸送量 $Q$, (管断面内を伝えられる単位時間当 りの熱輸送量), 実效熱拡散係数 $D_{\text {eff }}$, 仕事率 $W$ (単位 時間当りの仕事), 熱輸送効率 $\eta$ を求めた.

$$
\begin{aligned}
& Q=\frac{2 \pi}{T} \mathrm{j}_{t}^{t+T} d t \int_{0}^{d / 2}\left(\rho C u \theta-\lambda \frac{\partial \theta}{\partial x}\right) r d r \\
& D_{e f f}=4 Q /\left(\pi d_{e}^{2} C \rho \overline{d \theta / d x}\right) \\
& W=\frac{2 \pi L}{T} \int_{t}^{t+T} d t \int_{0}^{d / 2} u \frac{d P}{d x} r d r \\
& \eta=Q / W
\end{aligned}
$$

ここで，Cは作動流体の比熱であり， $\overline{d \theta / d x}$ は管断 面及び 1 周期で平均した温度の軸方向勾配の値である.

また, $d_{e}$ 洤付管の水力等価直径であり, 本論文 では次式によって定義した.

$$
d_{e}=\sqrt{4 V /(\pi d)}
$$

$V$ とLはそれぞれ溝付管の容積と長さである.

本研究では 1 周期平均の軸方向平均温度公配が一 定(前周期における値との差が $0.2 \%$ 末満) となるまで 計算を行い, 熱輸送量, 実効熱拡散係数, 仕事率, 熱 輸送効率などの計算には，流路端の影響が及ばない管 の中央部における速度分布，温度分布，圧力分布を用 いた. このときの速度分布，温度分布，圧力分布は 1 周期内の同一時点 $(t, t+T, t+2 T, \cdots)$ では同じである. すなわち，時間的に十分発展した速度分布，温度分布， 圧力分布となっている.

図 2 に溝幅 $S=15 \mathrm{~mm}$ の場合について，管中央部の軸 方向の平均温度分布を示す. 管断面の平均温度をさら
に 1 周期間で平均した平均温度の分布である. 曲線が 平均温度分布を示し，直線はその平均温度勾配である. 細線で示す平均温度勾配を $\overline{d \theta / d x}$ の值として用いた。 溝の無い直管部における平均温度は軸方向に向かって ほぼ直線的に减少しているが，溝部における平均温度 は必ずしも軸方向に低下しているとは限らない，この 原因としては，溝内部での渦の形成と排出があげられ る. 溝付管では, 軸方向温度勾配が一定值とならない ため，直円管内の振動流の場合のように，熱輸送量を 実効熱拡散係数で表すことができるかどうか検討を要 するが，本論文では，式(10)により求めた実効熱拡散 係数を図 3 に示してある.

図 3〜5にそれぞれ熱輸送量, 実効熱抬散係数, 仕 事率及び熱輸送効率と溝幅 $S$ との関係を示す．図には, Kaviany(2) による直円管の理論解も併せて示してある.

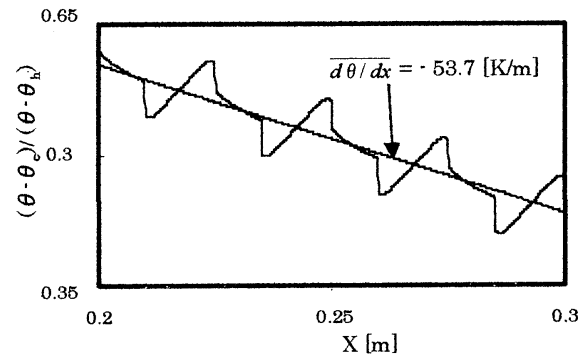

Fig.2 Distribution of mean temperature in the central part of grooved ducts with $S=15 \mathrm{~mm}$

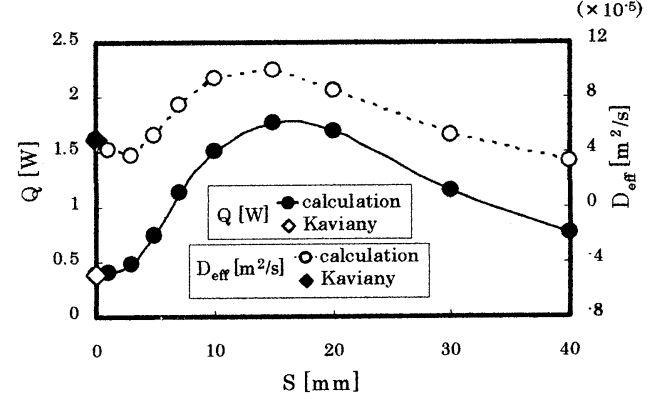

Fig.3 Relationship between heat transportation, effective thermal diffusivity and groove length

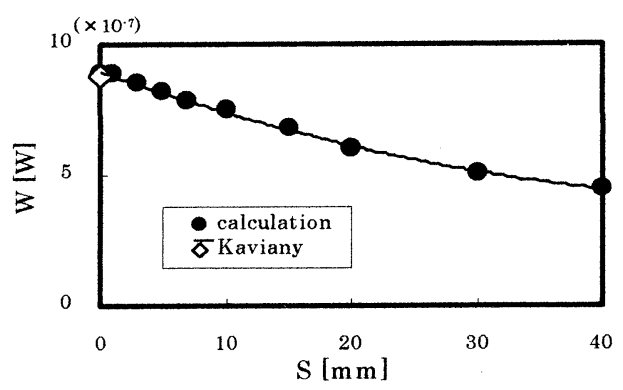

Fig.4 Relationship between work and groove length 


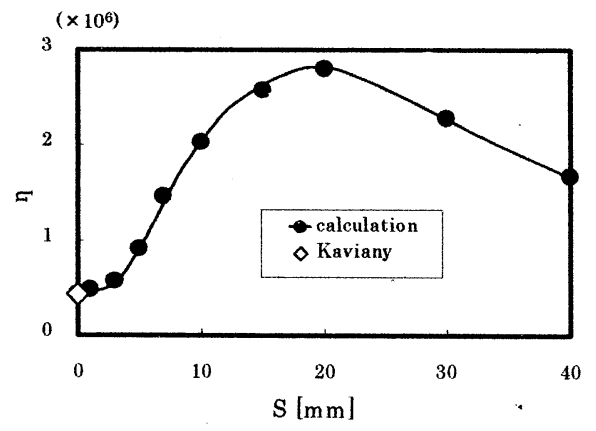

Fig.5 Relationship between heat transportation efficiency and groove length

溝付管の熱輸送量は $S=15 \mathrm{~mm}$ のときに最大となり, 直円管に比べて 4.5 倍程度となった. 仕事率は溝幅が 大きくなる程减少しているが，これは，溝幅 $S$ 大き い程等価直径が大きくなり，溝付管内における実効的 な振幅が堿少するためである. その結果, 熱輸送効率 は $S=20 \mathrm{~mm}$ のときに最大となり, 直円管に比べて約 6.4 倍となった. このように, 溝付管を用いることに より振動流の熱輸送量, 実効熱拡散係数及ひ熱輸送効 率は，いずれも増加することが分かった。

Ye 及び清水 ${ }^{(8)}$ の測定した実効物質拡散係数は $S=7$ $\mathrm{mm}$ のときに最大となっているのに対し, 本解析結果 では，S=15m のときに最大となっている.また，そ の最大值を Ye 及び清水が提案した無次元量 $D_{\text {eff }} /$ $\left(2 \pi f A m^{2}\right)$ で比較すると, 本解析值は 0.16 であるの に対し, Ye 及び清水の害験值は約 $0.05 \sim 0.09$ である. 本解析結果と $\mathrm{Ye}$ 及び清水の実験結果との差は, レイ ノルズ数 Re が異なるためであると考えられる. Ye 及び清水の実験における Re は 210～13,000 であり, 本解析值の 121 より大きい. また, 彼らの実験結果 から判断すると, 彼らの実験条件下における溝付管内 の流れは層流域に入っていなかったものと考えられる.

\section{2 流れ場と温度場の時間変化と熱埨送との関係}

図 6 に, 1 周期内の速度場と温度場の変化と熱輸送 向上との関係を示す。熱輸送量が最大となる溝幅が $15 \mathrm{~mm}$ 場合について示してある. 図の上半分に温度 場を示す. 黒色が温度の高い流体を示し, 白色が温 度の低い流体を示す。 また, 図の下半分に流れ関数 の等高線を示す．図の (a)の時点では, 管内を流れる 振動流の流速は大きく, 流体は高温側（左）から低温 側（右）に向かって流れている. 溝の中には循環渦が 形成されており，円管内の流れは溝中に流入しない。 すなわち，溝内の流体は閉じ込められた状態になって いる. したがって，(a)から(b)へと時間が経過するに

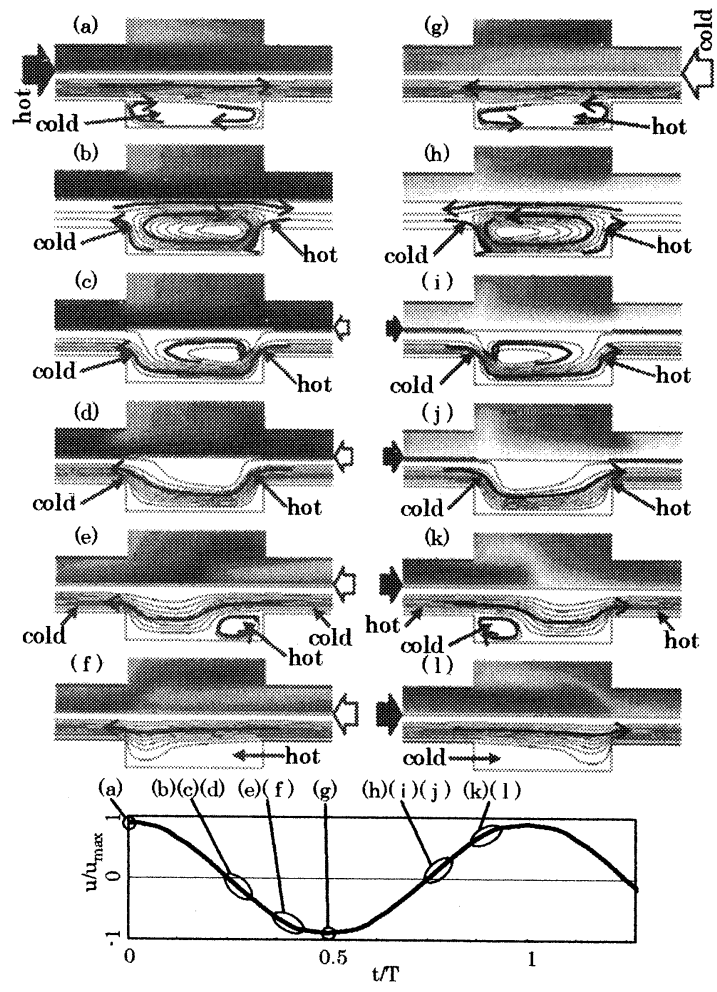

Fig.6 Transportation of cold and hot fluids towards hot and cold ends of grooved duct with $\mathrm{S}=15 \mathrm{~mm}$ $(\mathrm{t} / \mathrm{T}=(\mathrm{a}) 0,(\mathrm{~b}) 0.25$, (c) 0.275 , (d)0.3, (e)0.375, ( f ) 0.425 , (g)0.5,(h)0.75, (i ) $0.775,(\mathrm{j}) 0.8,(\mathrm{k}) 0.875,(\mathrm{l}) 0.925)$

伴い，管内を流れる流体の温度は溝の中の流体の温度 より高くなる. (b)〜 (d) の時点では, 管壁近傍の流れ は逆転する. しかも，この時点では流速が遅いため, 逆転した高温の流れは, 溝の中に流入し, 同時に, 溝 内に閉じ込められていた低温の流体は溝外に流出する。 流出した低温の流体は (d) 〜 (h) の間に管内を低温側 (右)加高温側(左)に向かって流れる. 一方, 溝内に は高温の流体が閉じ込められたままになっており， (d)から (h) 一と時間が経過するにともない，管内を流 れる流体の温度は溝内の流体より低くなる. $(\mathrm{h}) \sim(\mathrm{j})$ の時点では, 管壁近傍の流れは逆転し, 左から右に向 かって流れる. しかも，この時点では，(b)〜(d)の時 点と同様に，流速が遅いため，逆転した低温の流れは 溝内に流入し, 溝内を循澴していた高温の流体は溝外 に流出する. 流出した高温の流体は $(\mathrm{k}) \sim(\mathrm{l}) \sim(\mathrm{b})$ の 間に管内を高温側から低温側に向かって流れる.この ように，(a)〜(1)を繰り返すことにより，高温流体の 一部は高温側から低温側に向かって輸送され，低温流 体の一部は低温側から高温側に向かって輸送される. 
以上のように, 溝部において, 高温流体と低温流 体の取り込みと排出が交互に繰り返され，円管内にお いては排出された高温流体と低温流体の反対方向一の 輸送が行われる.このような流体の反対方向への輸送 に伴うエンタルピ輸送によって, 溝付管の熱輸送量は 向上したものと考えられる.この高温流体と低温流体 の反対方向への輸送は， 1 周期後に元の位置に戻る往 復輸送ではなく，周期を綝り返すごとに元の位置から 遠ざかる輸送であり，1 周期後に流体の全てが元の場 所に戻ることはない（直円管内の振動流では，1 周期 後には流体は元の場所に戻る）。本論文では，この流 体の輸送運動を Sobey (9) と同様に流体粒子の分散運動 と呼ぶことにする.

4.3 流体粒子の分散運動 以上のように, 溝付管 内の振動流による熱輸送は流体粒子の軸方向の分散運 動に伴うエンタルピ輸送が大きく寄与していると考え られる. そこで，流体粒子の分散運動を計算によって 解析した. 水中に水と同じ密度を持つ直径 $1 \mu \mathrm{m}$ の仮 想的な流体粒子を考え，この流体粒子が時間の経過と ともに溝付管内をどのように分散するかを調べた．流 体粒子の分散は, FUENT に組み込まれているラグラ ンジュの分散相モデルを用いて計算した.

すなわち，式(14)に示すラグランジュ的記述法によ る流体粒子の運動方程式(11)を解いて得られた粒子の速 度を積分することにより流体粒子の軌跡を求めた。

$\frac{d u_{p}}{d t}=F_{D}\left(u-u_{p}\right)+\frac{1}{2} \cdot \frac{\rho}{\rho_{p}} \cdot \frac{d\left(u-u_{p}\right)}{d t}+u_{p} \cdot \frac{\rho}{\rho_{p}} \cdot \frac{\partial u}{\partial x}$

$\frac{d v_{p}}{d t}=F_{D}\left(v-v_{p}\right)+\frac{1}{2} \cdot \frac{\rho}{\rho_{p}} \cdot \frac{d\left(v-v_{p}\right)}{d t}+v_{p} \cdot \frac{\rho}{\rho_{p}} \cdot \frac{\partial v}{\partial r}$

$F_{D}=\frac{18 \mu}{\rho_{p} D_{p}^{2}} \frac{C_{D} \operatorname{Re}}{24}$

$\mathrm{Re}=\frac{\rho D_{p}\left|u_{p}-u\right|}{\mu}$ 又は $\mathrm{Re}=\frac{\rho D_{p}\left|v_{p}-v\right|}{\mu}$

ここで， $F_{D}$ 及び Re は，それぞれ流体粒子に作用す る力とレイノルズ数である， $u, v$ は流体の速度, $u_{p}, v_{p}$ は粒子速度, $\mu$ は流体の粘度, $\rho$ は流体の密 度, $\rho_{p}$ は粒子の密度, $D p$ は粒子の直径, $C_{D}$ は抵抗係 数である. 抵抗係数の值としては下式を用いた。

$C_{D}=a_{1}+a_{2} / \mathrm{Re}+a_{3} / \mathrm{Re}^{2}$

上式中に含まれる定数の值としては Morsi ${ }^{(2)}$ らの值 を用いた. 式(14)（15)において右辺第2 項は仮想質量 の項，第 3 項は圧力勾配による力の項である.

流体粒子は速度分布が周期的な定常状態に発達し た後，平均流速が最大となる瞬間(図 6 で(a)の時点) に注入した. 注入した流体粒子数は的 12,000 から

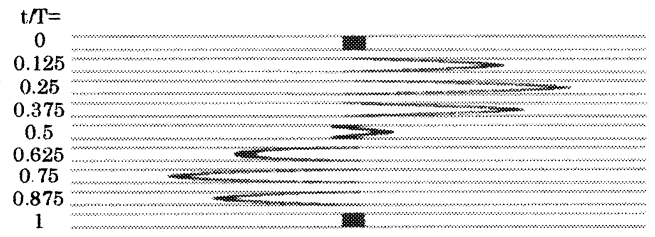

(a) Straight round duct

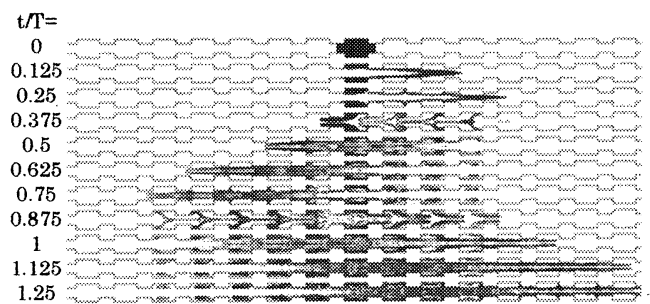

(b) Grooved duct with $S=15 \mathrm{~mm}$

Fig. 7 Dispersion of fluid particles in straight round duct and grooved duct with $S=15 \mathrm{~mm}$

40, 000 個であり，注入位置は，溝付管中央の 1 ピッチ 分の幅内である（ただし，直円管では $10 \mathrm{rm}$ の幅内. $S=15 \mathrm{~mm}$ では $25 \mathrm{~mm}$ の幅内である).

図 7 (a) (b) に直円管内と $S=15 \mathrm{~mm}$ の溝付管内を流体 粒子が 1 周期の間に管中央部から管の両端方向に向か って分散していく様子を示す。眓 7 (a)に示すように, 直円管内では，流体粒子は周期的な速度分布の変化に 従って移動するが，1 周期後には全ての流体粒子が元 の位置に戻っている.すなわち，流体は往復運動を繰 り返すのみである。一方，図７(b)に示すように溝付 管内に扩いては，最初流路の中央に位置していた流体 粒子は 1 周期後に元の位置に戻ることはなく, 流路の 両端に向かって分散している. 図 7 (b) から分かるよ うに, $t / T=0 \sim$ 約 0.25 の間は流体が速い速度で右方 向に流れている. そのため, 溝部では流れの剥離によ って溝内に循環渦が形成され，円管部の流体粒子が溝 内に流入することはない：流れ方向が逆転する $t / T=$ 約 $0.25 \sim$ 約 0.375 の間は流速が遅いために溝部で流れ は剥離せず円管部から溝内に流入する流れが形成され る. その流れに乗って流体粒子が溝内に流入する. $t / T=$ 約 $0.375 \sim$ 約 0.75 の間は流速が再び速くなるた め, 溝内には剥離循環渦が形成され，円管部の流体粒 子は溝内に流入することなく流路の左方に向かって流 れる. そのため, $t / T=0.75$ の時点（振動運動により 流体が最も左方に移動した時点）においては, 流路の 右半分では流体粒子は溝内のみに留まっており，円管 部には流体粒子は存在していない，流れ方向が逆転す る $t / T=$ 約 $0.75 \sim$ 約 0.875 では流速が遅いため, 流路 の左半分に掠いては円管部の流体粒子が溝内に流入す 
る. また, 流路の右半分においては, 溝内一の流体粒 子の流入とともに溝内の流体粒子の一部は円管部に流 出し, 残りの粒子は溝内に留まっている. その後の $t / T=$ 約 $0.875 \sim$ 約 0.125 の間では流速が速いため, 溝 内には剥離循環渦が形成され，円管部の流体粒子は溝 内に流入せず，円管部を右方に向かって流れる．その 結果, $t / T=0.125$ の時点においては, 流路左半分には, 流体粒子は溝内の外留まっており，円管部には流体 粒子が存在しない，しかし，流路の右半分に执いては, 溝内から排出された流体粒子が円管部の流れによって 右方向に輸送される.

このように, 溝付管内に执いては, 流体粒子は流 路の長さ方向に連続的に分散するのではなく, 溝内に 不連続に分散寸る流体粒子と, 円管内に連続的に分散 する流体粒子とが重站合わさった分散運動になる。

図8に溝幅 $S$ を変化させた場合について, 2 周期後 の流体粒子の分散状態を示す．溝幅が大きくなるにつ れて左右方向一広く分散吉るようになる. 溝幅 $S$ が $15 \mathrm{~mm}$ 前後の流路の場合に最も広い範囲にわたって分 散しており，满幅 $S$ の值がそれ以上になると分散の範 囲は狭くなっている。

4.4 温度分布の時間発達 前節では, 振動流の 平均流速が最大となった時点で, 溝付管中央部の 1 ピッチ分に仮想流体粒子を投入し，その流体粒子の分 散運動を調べた、本節では，仮想流体粒子を投入する 代わりに溝付管中央部 1 ピッチ分の温度を $343 \mathrm{~K}$ に 設定し, その結果形成される矩形型温度分布が振動運 動の進展とともにどのように発展するか老調べた.

温度分布の時間発展は基礎式(1) (4)を境界条件(5) 〜(8)の下で解いた. ただし, 温度の境界条件として 式(5)の代わりに下式(19)を用いた.

$\boldsymbol{x}=0$ で $\theta=293($ for $u \geq 0), \frac{\partial \theta}{\partial x}=0($ for $u \leq 0)$

温度の初期条件として下式を与えた。

$0 \leq x<x_{1}, x_{2}<x \leq$ 約 0.5 で $\theta=293$,

$x_{1} \leq x \leq x_{2}$ で $\theta=343$

ここで, $x_{I} \sim X_{2}$ が矩形型温度分布 (高温部) の範 囲である. 速度の初期条件としては時間的に十分発達 した速度分布を与えた。

図9(a)には，S=0 mm の直管内における矩形型初 期温度分布の 1 周期内の時間発展を示す. 水の熱抬散 係数がゼロでないため, 半径方向の熱伝導によって往 流と復流の半径方向温度分布が異なり, その結果, 往 復運動に伴う軸方向のエンタルビ輸送によって多量の 熱が軸方向に輸送される.この熱量は熱伝導により軸

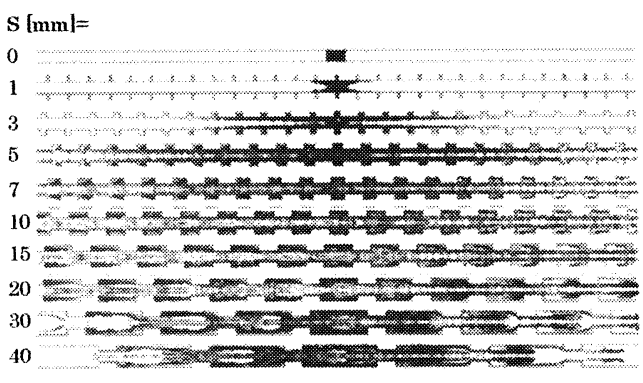

Fig.8 Comparison of dispersion of fluid particles for the ducts with $S=0-40 \mathrm{~mm}$ after 2 cycles of oscillation

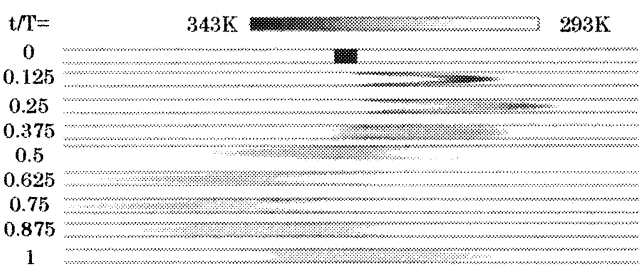

(a) Straight round duct

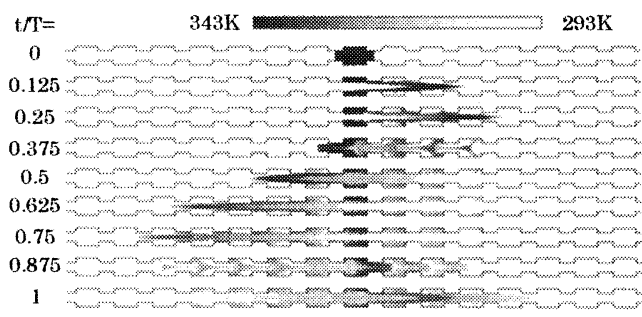

(b) Grooved duct with $S=15 \mathrm{~mm}$

Fig.9 Dispersion of heat in straight round duct and grooved duct with $S=15 \mathrm{~mm}$

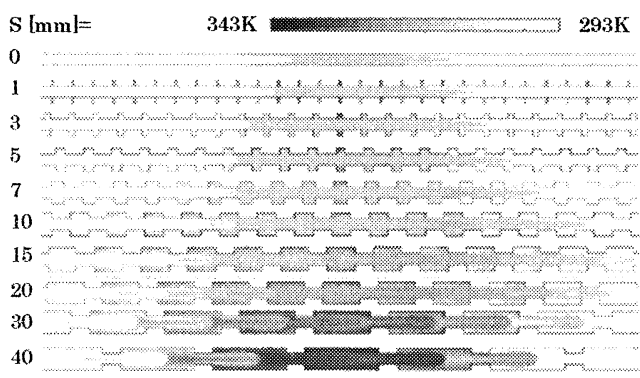

Fig. 10 Comparison of dispersion of heat for the ducts with $S=0-40 \mathrm{~mm}$ after 2 cycles of oscillation

方向に輸送される熱量に比べて約 330 倍である. その ため，直円管においても 1 周期後の温度分布は初期の 矩形型温度分布には戻らず，軸方向に広がった温度分 布となっている. 
図 9(b)には, $S=15 \mathrm{~mm}$ の溝付管における矩形型初 期温度分布の 1 周期内の時間発展を示す. 1 周期後の 温度分布は軸方向の広い範囲にわたって広がり, 初期 の矩形型温度分布とは全く異なった分布となっている.

図 10 に溝幅が $0 \leqq S \leqq 40 \mathrm{~mm}$ の溝付管における 2 周期後の温度分布の比較を示す. 溝幅 $S$ が大きくなる につれて, 軸方向のより広い範囲に広がった温度分布 になり, $S=15 \mathrm{~mm}$ の溝付管の温度分布が軸方向に最も 広がった温度分布となる. 溝幅が $15 \mathrm{~mm}$ よ大きくな ると温度分布の広がり幅は堿少に転じている.

4.5 流体粒子の分散運動と熱翰送との関係 上述 のような温度分布の時間発展は, 当然軸方向の熱輸送 によりもたらされるものである. ここで, 図 8 と図 10 を比較して分かるように, 流体粒子の分散の様子 と温度分布の広がりの様子はよく似ており, 流体粒子 の分散運動が熱輸送に大きく寄与していると思われる. そこで, 流体の軸方向への分散運動が熱輸送にど の程度寄与するかを検討するため, 流体の分散と熱の 分散を比較した. Sobey(9)は波状流路内における流体 粒子の分散運動の大きさを表すのに式(21)で定義され る分散を用いている. 本研究でも, Sobey と同じ下式 で定義される分散を用いた.

$$
\sigma_{f}^{2}=1 /(N-1) \sum_{i=1}^{N}\left(x_{i}-x_{0}\right)^{2}
$$

ここで, $N$ は流体粒子の個数, $x_{i}$ は $t$ 時間後におけ る $\mathrm{i}$ 番目の流体粒子の $\mathrm{x}$ 座標, $\mathrm{x} 0$ は流体粒子群の初期 時点における重心座標である.

温度の分散は次式によって定義した。

$$
\sigma_{t}^{2}=\frac{1}{\left(\theta_{h}-\theta_{c}\right) V_{i n i}} \cdot \stackrel{L}{L}\left(x-x_{0}\right)^{2}\left\{\bar{\theta}(x)-\theta_{c}\right\} A(x) d x
$$

ここで, $\theta_{h}$ は矩形型初期温度分布における溝付管 中央部における温度 (高温) , $\theta_{\mathrm{c}}$ は中央部の両側に おける温度 (低温), $x$ は軸方向座標, $\bar{\theta}(x)$ は $x$ に おける断面内の平均温度, $x$ o は矩形型初期温度分布の 中心位置である（xoに対して軸対象の矩形型温度分

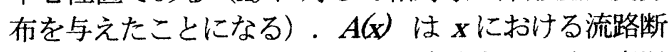
面積である. $V_{\text {in }}$ は矩形型初期温度分布における高温 部の体積である. したがって, 流体の密度 $\times$ 流体の比 熱 $\times\left(\theta_{m}-\theta_{c}\right) \times V_{i m i}$ は矩形型初期温度分布において流 路中央部（高温部）に与えたエンタルピとなる.

図 11 に 3 周期後までの流体粒子の軸方向分散 $\sigma^{2}{ }_{f}$ を满幅 $S$ をパラメータにとって示す. $S$ が $0 \mathrm{~mm}$ の直 円管の場合を除き，溝付管の分散 $\sigma^{2}{ }_{f}$ はいずれの場 合もサイクル数の増加と伴に増加している.

図 12 に熱の分散 $\sigma^{2} t$ の各周期の值を示す. 熱の分 散 $\sigma^{2} t$ は, 直円管 $(S=0 \mathrm{~mm})$ も含む全ての流路にお
いて, サイクル数の増加とともに大きくなっている. なお, 流体の分散の值は分子運動に基づく熱の拡散係 数がゼロの場合の熱の分散の值に等しい.

図 13 に 1 周期後の流体粒子の分散 $\sigma^{2}{ }_{t}$ と熱の分散 $\sigma^{2}{ }_{t}$ の比較を示す. 流体粒子の分散 $\sigma^{2} t_{t}$, 熱の分散 $\sigma^{2}{ }_{t}$ のいずれも，溝幅 $S$ が 10〜 $15 \mathrm{~mm}$ のとき最大值を とる山形の分布をしている. また，約 $40 \mathrm{~mm} \geqq S \geqq$ 的 $5 \mathrm{~mm}$ の溝付管においては, $\left|\sigma^{2}{ }_{t} \cdot \sigma^{2}{ }_{t}\right| / \sigma^{2} t_{t}<0.31$ で ある.すなわち，熱の分散の值 $\sigma^{2}$ と流体粒子の分散

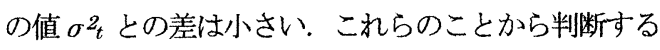
と, 約 $40 \mathrm{~mm} \geqq S \geqq$ 約 $5 \mathrm{~mm}$ の溝付管における熱輸送に

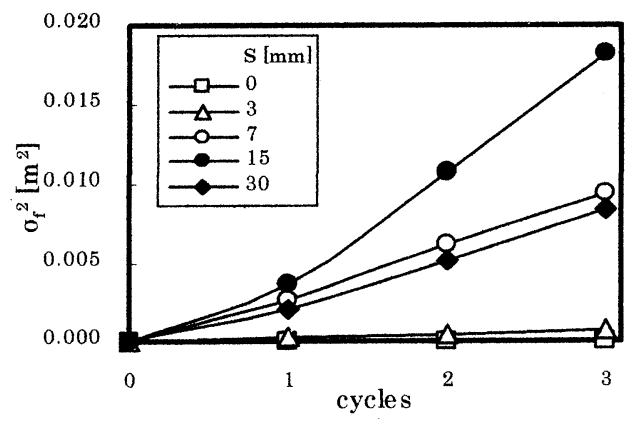

Fig. 11 Comparison of dispersion of fluid particles for ducts with various $S$

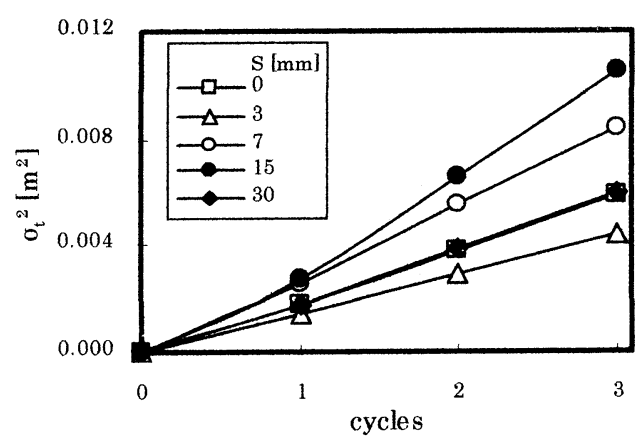

Fig. 12 Comparison of dispersion of heat for ducts with various $S$

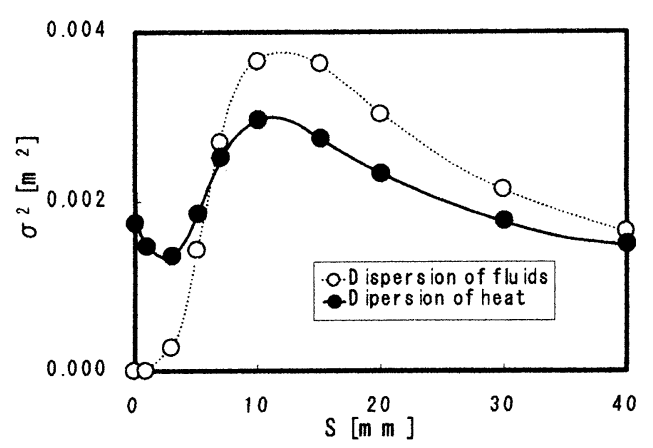

Fig.13 Comparison of $\sigma^{2}$ with $\sigma^{2}{ }_{t}$ 
おいては，流体粒子の分散運動による熱輸送が大きな 役割を果たしていると言える. 特に, $S=10 \sim 15 \mathrm{~mm}$ の 溝付管の熱輸送は主として流体粒子の分散運動によっ て行われ，それゆえ， $S=10 \sim 15 \mathrm{~mm}$ 溝付管の熱輸送 が最大になっていると考えられる. $S=10 \sim 15 \mathrm{~mm}$ 溝 付管における熱の分散の值 $\sigma^{2}{ }_{t}$ が流体粒子の分散の值 $\sigma^{2}{ }_{t}^{2}$ よりささなるのは, 熱の分子拡散により, 流体 の温度分布が一様に近づくため, 流体粒子の分散運動 によって輸送されるエンタルピが熱の分子拡散がゼロ の場合のエンタルピ輸送量より堿少するためであると 考えられる.

溝幅が 10 15 mm 以下において, 流体粒子の分散 の值が小さくなるのは，流れの逆転時に円管部から溝 内に流入する流体の量が少なくなり，円管部之溝内の 流体との入れ替わり量が少なくなるためである.

すなわち，図6の(b)〜(d)の時点，及び，(h)〜(j)の 時点における溝内の流体と円管部の流体の入れ替わり 量が少なくなるためである. また, 溝幅が $10 \sim 15 \mathrm{~mm}$ より大きくなると，流体粒子の分散の值が小さくなる のは, 流速の速い時点においても溝内に円管部から流 体が流入し，溝内全体にわたる剥離循環渦が形成され なくなるためであると考えられる.

なお, $S=1 \mathrm{~mm}$ と $3 \mathrm{~mm}$ 溝付管における熱の分散 の值の方が直円管の值よりも小さくなっているが，こ れは, 初期状態において, 溝付管中央部 $\left(\mathrm{x}_{1} \leqq \mathrm{x} \leqq\right.$ $\mathrm{x}_{2}$ ）の溝内に投入されたエンタルピの大部分が溝内 に滞留し, 溝の開口部近辺のエンタルピのみが軸方向 に輸送されるためである.

\section{5. 結 論}

縮小部の直径が $6 \mathrm{~mm}$, 溝部の直径が $12 \mathrm{~mm}$, 縮小部 の 1 区間長さが $10 \mathrm{~mm}$, 溝幅が 0 40 mm の溝付管に振 動流を与えた場合の軸方向の熱輸送量, 実効熱拡散係 数, 仕事率, 熱輸送効率と流体粒子の分散及び熱の分 散を数値解析によって求め, 以下の結論が得られた.

(1) 熱輸送量は溝幅が $15 \mathrm{~mm}$ 溝付管が最大であり, そのときの熱輸送量は直円管の約 4.5 倍であった.

(2) 熱輸送効率は溝幅が $20 \mathrm{~mm}$ の溝付管が最大であり, そのときの熱輸送効率は直円管の約 6.4 倍であった.

（3）約 $40 \mathrm{~mm} \geqq S \geqq$ 約 $5 \mathrm{~mm}$ の溝付管における熱輸送にお いては，流体粒子の分散運動による熱輸送が大きな 役割を果たしている.

（4）流体粒子の分散の値は, $S=10 \sim 15 \mathrm{~mm}$ 溝付管が 最大である. そのため, $S=10 \sim 15 \mathrm{~mm}$ 溝付管の熱 輸送量も最大になる.

\section{参考文献}

(1) Kurzweg U.H. and Zhao L., Heat transfer by high-frequency oscillations, Phys. Fluid, Vol.27, No.11, (1984), pp.2624-2627.

(2) Kaviany M., Performance of a Heat Exchanger Based on Enhanced Heat Diffusion in Fluids by Oscillation, Trans. ASME, J. Heat Transfer, Vol.112, (1990), pp.49-55.

(3) Nishio S. et al.,1994, Oscillation-controlled heat transport tube (1st report, Effect of liquid properties), Trans. JSME, Vol.60, No.569B, (1994), pp.233-239.

(4) Nishio S. and Zhang W.M., Oscillationcontrolled heat transport tube (2nd report, Optimum condition), Trans. JSME, Vol.60, No.570B, (1994), pp.627-633.

(5) Nishio S. et al, Study on oscillation-controlled heat transport tube (3nd report, Inverted oscillation phase heat transport tube), Trans. JSME, Vol.60, No.578B, (1994), pp.3498-3503.

(6) Ohno Y. et al., Enhanced heat transfer during oscillatory flow in annular channels, Trans. JSME, Vol.70, No.698B, (2004), pp.2612-2619.

(7) Inukai A et al, Characteristic of heat transportation by an oscillatory flow, Trans. JSME, Vol.71, No.710B, (2005), pp. 2515-2522.

(8) Ye X. and Shimizu M., Augmented longitudinal diffusion in grooved tubes for oscillatory flow, J.Heat and Mass Transfer, 44, (2001), 633-644

(9) Sobey I.J., Dispersion caused by separation during oscillatory flow through a furrowed channel, Chemical Engineering Science, 40-11, (1985), 2129-2134

(10) Hino H., Sawamoto, M. and Takasu, S., Experiments on transition to turbulence in an oscillatory pipe flow, J. Fluid Mech., 75 part2, (1976), 193-207.

(11) FLUENT 6.1 Users Guide, Fluent Inc., (2003).

(12) Morsi S.A. and Alexander A.J., An Investigation of Particle Trajectories in TwoPhase Flow Systems. J. Fluid Mech., 55(2), (1972), 193-208. 